Article

\title{
Personality Traits and Stock Investment of Individuals
}

\author{
Cheng-Po Lai ${ }^{(\mathbb{D}}$ \\ Department of Finance \& Graduate Institute of Financial Management, Nanhua University, \\ Chiayi 62249, Taiwan; paulai@nhu.edu.tw; Tel.: +88-65-272-1001 (ext. 56228)
}

Received: 25 August 2019; Accepted: 30 September 2019; Published: 2 October 2019

check for updates

\begin{abstract}
Behavioral finance has been widely applied in the financial realm from psychological perspectives focusing on herding and disposition effects. However, little research is devoted to the influences of personality traits on the stock investment intentions of individuals. This study extends the theory of planned behavior incorporating the big five personality taxonomies to investigate the effects of the personality traits of individual investors on stock investment intention. Utilizing partial least squares based on structural equation modeling techniques with a sample of 385 subjects, empirical results indicate that the stock investment intentions of individuals are significantly affected by subjective norm, attitude, and perceived behavioral control, and subjective norm significantly affects attitude. Individuals with open and agreeable personalities tend to have influences on subjective norm. Neurotic individuals tend to have negative attitudes toward stock investment. The perceived behavioral control of individuals regarding stock investment is influenced by the personality traits of agreeableness, extroversion, conscientiousness, and openness. Prior stock trading experiences significantly affect the relationships between attitude and stock investment intention, as well as on the linkages between extroversion and subjective norm, attitude, and perceived behavioral control. This study concludes with the discussion of the findings, with insights into theory and managerial implications.
\end{abstract}

Keywords: personality traits; big five; individual investors; stock investment; theory of planned behavior; partial least squares

\section{Introduction}

Sustainable development has emerged as the latest catchphrase over the last decades and has become an essential part of the strategic planning processes of firms. Regarding the financial sector, capital markets should facilitate the raising of capital at low costs for firms to finance their efforts to become sustainable [1]. Waygood [2] indicated that this role has been weakened due to the inefficiencies of capital markets. The inability of the predictive power of investors is the main reason for market inefficiency, which results in the failure of the market to recognize and reward the right conduct of firms to become sustainable. Shantha [1] suggested that the information on the sustainable development efforts of companies is not completely and rapidly included into these company stock prices if the participants in the stock market have biases in their behaviors. Compared with institutional investors, individual investors are less sophisticated because of limited attention, memory, time, profession, and processing infrastructure. Therefore, individual investors tend to use simple heuristics or rules of thumb in making decisions, which become maladaptive in the real dynamic stock markets [3,4].

The general assumption is that it is worth increasing investors' participation in direct trading activities in stock markets since the performance of the stock market is strong compared with other investment choices historically [5]. The Taiwan Stock Exchange (TWSE) began operations with only 18 security agency companies listed in 1962. According to the annual statistics report of the World 
Federal Exchange, the total value of the market capitalization of TWSE reached US\$ 596 billion, ranking 20th globally in 2006 [6]. Traders in the TWSE are typically categorized into individual and institutional investors. The stock market in Taiwan is unique because individual investors accounted for approximately $90 \%$ of all stock trading volumes from 1995 to 1999 [7], and the ratio of individual investors was high, reaching $72.8 \%$ in 2006. However, given the impact of the 2008 financial crisis and subsequent financial fraud, the ratio of individual investors decreased to $48 \%$ in 2015 [8]. Figure 1 presents the fraction of market capitalization held by institutional and individual investors over the period of 2005-2017 [8].

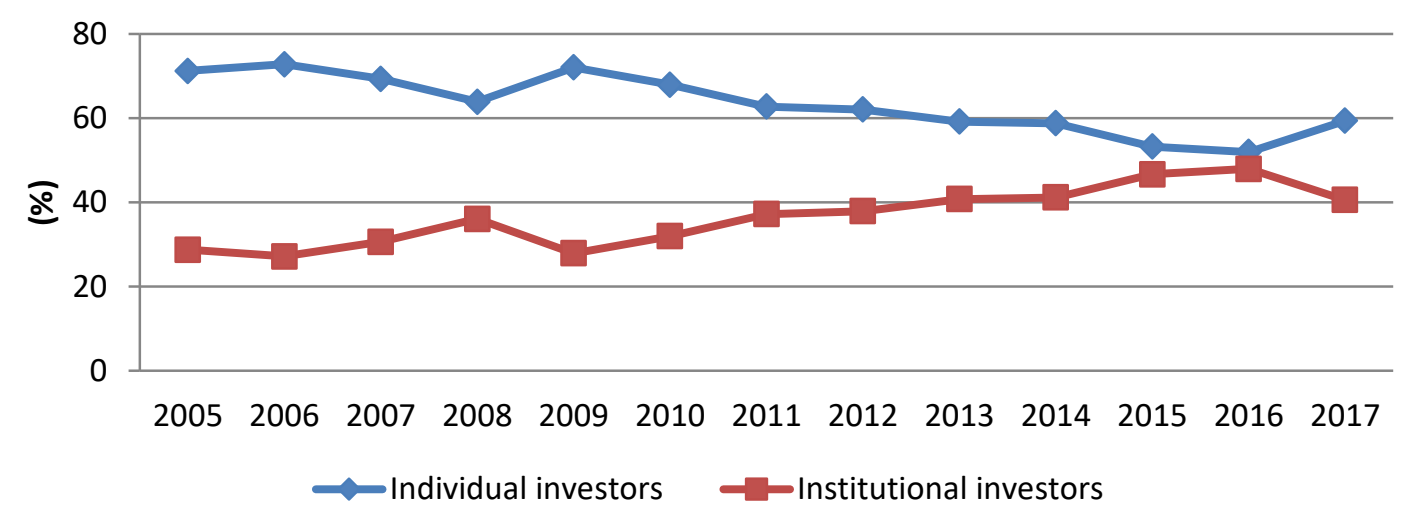

Figure 1. The fraction of market capitalization held by each investor type. Note: the data of the individual and institutional investors are retrieved from the Taiwan Stock Exchange Corporation [8].

Gordon [9] proposed the "Myron Gordon's Dividend Growth Model" that explains how the dividend policy of a firm is the basis for establishing share value, assuming that future dividends will grow at a constant rate in perpetuity. The Gordon [9] growth model is widely applied in financial academics and relies on the assumption that firms have sustainable development to distribute dividends constantly. Besides, the sustainability of corporate finance means the maximization of shareholders' wealth with high growth rate based on a stable financial condition while not depleting its financial resources. Stability is primarily reflected in the rapid and stable cash flow. However, lack of capital inflow would have great impacts on firms' capability in investment and efficiency when allocating their resources [10]. However, financial fraud, such as that committed by Enron and WorldCom, has become prevalent. In 2001, the Enron case impelled the US Congress to pass the "Sarbanes-Oxley Act" to set new or expanded requirements for all public company boards, management, and public accounting firms. Following the 2001 Enron scandal, a series of corporate frauds also occurred, and numerous firms declared bankruptcy in Taiwan. Procomp Informatics Ltd., one of the largest listed firms in Taiwan, astonished investors in 2004 by defaulting on corporate bonds worth NT $\$ 2.98$ billion (US\$95,666 million). Nearly 30,000 investors, among whom more than 20,000 shareholders hold stock in the company, were affected in this scandal. Numerous families were hit significantly by the losses [11]. In 2006, the Rebar Asia Pacific Group was engaged in a high-profile embezzlement case. The Rebar Group is one of the top family businesses in Taiwan and was involved in various industries, including construction, real estate, hotel, vehicle, non-life insurance, retail services, banking, media, and textiles. Corporate fraud by the Rebar Group exposed the agency problems present in family-owned businesses. Some internal managers or shareholders take advantage of their business operations for self-interest [12]. The detection of financial fraud, which causes decreases in dividend and capital gains for investors, became difficult, particularly for individual investors. Thus, the sustainable development of firms in Taiwan was seriously affected by the loss of participation of individual investors in the stock market.

Traditional finance theories propose that people behave rationally and their behaviors can be predicted. However, recent empirical research has indicated that it is difficult to justify investors' behaviors via conventional rational theories, including the capital asset pricing model (CAPM), 
which shows how investors chose their portfolios on the efficiency frontier, given their preferences and tradeoffs between expected returns and risk [13-15], and the efficient market hypothesis (EMH), which states that the capital market is efficient if security prices accurately reflected all relevant information in determining those prices [16], because market participants in the real world often behaved unpredictably. The perceptive factors that may influence the behaviors via psychological and personal characteristics have been neglected. Behavioral finance helps explain these phenomena by considering the perspectives of psychology [17].

Andersson, Hedesström, and Gärling [18] identified a social-psychological aspect that conceived herding as an informative social influence from heuristic or systematic information processes. Stock investors made the predictions of future stock prices based on various sources of information [19]. Hoffmann, Post, and Pennings [20] found that investors' cognitions were important in deciding their actual behaviors in trading and risk-taking activities. Yeh and Li [21] indicated eight psychological states of investors that affected the stock market from the interaction among investor sentiments, whether herding or non-herding, such as suspicion, hope, optimism, euphoria, overconfidence, ambivalence, pessimism, and fear. Every psychological state had a significant influence on the market returns. The other main issue in behavioral finance is disposition effect, defined as the phenomenon that investors tend to keep losing positions too long and to sell winning positions too early [22]. Research in different trading contexts and cultures has reported the effects of disposition [23,24]. Kadous et al. [25] reported that investors with higher self-regard held losing investments shorter than those with lower self-regard.

Previous studies in the behavioral finance literature have centered on herd bias and disposition effects. Nonetheless, little literature is found regarding the effects of personality traits on the stock investment intentions of individuals. In addition, to realize the behaviors of stock investors, this study is also concerned with the individuals who have not been involved in direct trading in stock markets but could be potential investors that are motivated to participate in stock investment. For governments and institutions that regulate and facilitate stock market participation, a corresponding need exists to recognize the perceptions of individuals toward stock investment that can be encouraged and enhanced with the policy goal to promote wide stock ownership. An understanding of the intentions of individual stock investors would also have great practical value, especially for managers of security firms seeking to manage stock trading effectively and recognized individual stock investors' needs for the improvement of the services of their firms. With these motivations, this study is the first attempt to examine how the big five personality characteristics influence individual investors in their cognitions and intentions in investing in the stock markets.

This study has several contributions to the academia and industry. First, according to the behavioral finance literature, a comprehensive examination of the stock investment intentions of individuals has not been conducted. This study provides empirical evidence on how personality traits influence individual perceptions, which in turn affect their intentions to participate in the stock markets. Second, this study is the first to apply the theory of planned behavior (TPB) model [26] and extend this model with the big five personality characters in the investigation of the perceptions and intentions of individual stock investors in the financial sector. The results demonstrate that subjective norm, attitude, and perceived behavior control are identified to have significant effects on the stock investment intentions of individuals. Personality traits, such as agreeableness and openness to experience, are shown to significantly affect subjective norm. Extroversion, conscientiousness, and openness to experience are revealed to significantly influence perceived behavioral control. Third, this study discovers the moderating roles of gender, age, and stock trading experience in the research. Gender is indicated to have only a significant effect on the relationship between conscientiousness and attitude. Age is shown to have a significant influence on the relationship between extroversion and perceived behavioral control. Prior stock trading experiences are shown to significantly moderate the relationships of attitudes to stock investment intention, as well as extroversion to subjective norm, attitude, and perceived behavioral control. Fourth, to distinguish from previous research on 
personality traits and investment choices that is conducted on the basis of experimental or clinical designs with limited samples from students $[27,28]$, the empirical data of this study are collected from 385 respondents who are more than 20 years old and eligible to participate in Taiwanese stock markets. Fifth, the findings of this study provide suggestions for governments and security practitioners to have good policies and promotion to encourage individual investors to invest in the stock markets, which would provide financial support for firms in pursuing sustainable development.

The remainder of this paper is structured as follows. Section 2 provides the literature review on $\mathrm{TPB}$; personality traits; and the moderating roles of gender, age, and experience, which are associated with the hypotheses in this study. The research design and methodology is described in Section 3. Section 4 describes the results related to the constructs' reliabilities and discriminant validities in the measurement model and hypothesis tests in the structural model. Section 5 concludes the paper with its theoretical remarks and practical implications and provides limitations and the directions for future research.

\section{Literature Review and Hypotheses}

\subsection{Theory of Planned Behavior}

Ajzen and Fishbein [29] suggested theory of reasoned action (TRA), which states that behavioral intentions were perceptive and act as a sign of the inclination of an individual to conduct a particular behavior. Extended from TRA, TPB proposed that behavior was decided by intention (i.e., incentive to perform a specific behavior) and perceived behavioral control (i.e., perceptions of whether a person had the relative resources to perform such a behavior) [26,30]. Behavioral intentions were posited to be influenced by the main independent cognitions: attitude (attitudinal evaluations about acting the behavior), subjective norm (perceived social pressure from other people who were important to an individual to perform the behavior), and perceived behavioral control (the amount of control that individuals perceived that they had over performing the behavior) [31]. Chang [32] investigated the consumer's behavioral intention for a mutual fund and found that subjective norm and attitude toward the behavior significantly affected the mutual fund investors' behavioral intentions. Yen, Chang, and $\mathrm{Wu}$ [33] employed TPB to probe into the accountants' behaviors with regard to earnings management and identified attitude to be the significant construct of TPB that explained the earnings management intention of accounting practitioners. Subjective norms, attitude and moral norms were found to affect the intention which in turn influenced behavior towards socially responsible investment (SRI) [34]. Andersson, Hedesström, and Gärling [18] suggested herding as the phenomenon that investors tend to be affected by other people in perceiving and participating in the stock market. Herding is suggested to be a form of social influence in stock markets. These social influences include normative (i.e., having the motive to conform to others from external social pressure or internal social norms) and informative (i.e., having the incentive to get useful information from others). Perceived behavioral control is defined as the perceptions concerning whether a person had sufficient resources to perform the behavior [27]. In this study, perceived behavioral control is referred to the resources (such as information and knowledge) by which individuals perceive stock investment. Based on $\mathrm{TPB}$, it is postulated that the subjective norm arising from peers or the family, individuals' attitudes towards stock investment, and their perceived control of the resources for stock investment, will affect individuals' intentions to participate in the stock market. Therefore, this study suggests the hypotheses as follows.

Hypothesis 1 (H1). Subjective norm positively affects the stock investment intentions of individuals.

Hypothesis 2 (H2). Attitude toward stock investment positively affects the stock investment intentions of individuals.

Hypothesis 3 (H3). Perceived behavioral control positively affects the stock investment intentions of individuals. 
Chang [35], Han et al. [36], and Ryu and Jang [37] have demonstrated that subjective norm has a direct effect on attitude toward a behavior. The current study examines individuals' intentions to invest in stock markets in Taiwan, in which the culture is that people are easily affected by others and the media. There are several channels discussing the stock markets and providing the knowledge and analysis regarding stock investing in Taiwan. Whether stock investment is an intelligent choice for an individual would be influenced by the peer's opinions and financial experts' opinions. Hence, subjective norm is proposed to affect the attitude of an individual toward stock investment.

Hypothesis 4 (H4). Subjective norm positively affects the attitudes of individuals toward stock investment intentions.

TPB has been applied widely to account for the complexity of influences in the behavioral decision-making via the identification of the predictors of the behavior of an individual [38] in various studies, such as food consumption decisions [39], intention to use digital coupons [40], and purchase intention of green products [41]. A few applications of TPB have been conducted in the financial field. Farah [42] employed TPB to examine the switching intentions of customers in the banking sector. Bolton et al. [43] applied TPB to address that lowered risk via a remedy that would increase the behavioral intentions to conduct riskier behavior. However, a research model that incorporates TPB and the big five-personality inventory as the antecedents influencing subjective norm, attitude, and perceived behavioral control of individuals has not been proposed. This study aims to fill this research gap by utilizing the widely accepted trait measurements for personality to extend TPB, particularly in exploring the stock investment intentions of individuals.

\subsection{Personality Traits}

Norman [44] suggested emotional stability, extroversion, culture, agreeableness, and conscientiousness to be the inventory of personality. The list of adjectives as regards with personality was identified as the big five trait taxonomy which includes extroversion, agreeableness, conscientiousness, neuroticism, and openness [45]. Researchers have shown that personality traits could predict numerous scopes of human behaviors, preferences, and effects [46]. Personality traits were revealed to correlate with sales performance [47], academic success [48], and attitudes toward materialism and money [49]. Regarding the financial arena, personality characters were shown to correlate with short-term versus long-term investment choices [50], as well as investors' risk-taking activities and their performance in investment portfolio [27,51]. Mayfield et al. [50] investigated several psychological antecedents of investment intentions and suggested that extroverted individuals have higher intentions for short-term investing, whereas those with more neuroticism and risk aversion characteristics avoided investing in short-term instruments. Durand et al. [51] discovered that the personalities of investors were associated with their decision-making regarding investment portfolios and results. Durand et al. [27] identified that the reliance of individuals on the availability heuristic and disposition effect was associated with their personality traits. Ben-Shahar and Golan [46] provided empirical evidence that personality traits and individual inclinations were related to their characteristics in housing tenure, and investment behaviors in real estate. Chang et al. [52] found that the investors in mutual funds exhibit personality traits of confidence, optimism, approachability, high emotional intelligence, and flexibility. Personality traits affected the behaviors of mutual fund investors significantly, and the characteristics of individuals affect personality traits and their investment behaviors. Furthermore, it was proposed that individuals with high levels of extroversion and openness had higher risk tolerance than those with high levels of conscientiousness [53]. Oehler et al. [28] provided experimental evidence that extroversion and neuroticism significantly influenced the behaviors of individuals. Individuals who were extroverted were shown to pay more for financial assets, and individuals who were neurotic held assets with less risk. 
Durand et al. [51] indicated that personality is a "motivator" of human behavior. A growing literature shows that the investment decisions of individuals are affected by personality traits. However, previous studies have emphasized how personality influences the investment behaviors of individuals after involvement in stock, mutual fund, or real estate investments. For those who have not invested in the stock market, how personality traits motivate these individuals to invest remains unknown. This study thus applies TPB $[26,31]$ to fill the research gap as TPB provides a useful model for the identification of the potentially modifiable determinants of investment behavior.

Svendsen et al. [54] advocated that the effects of extroversion and conscientiousness on behavioral intention were revealed to be mediated by subjective norm. Nonetheless, little literature can be found investigating the effects of personality traits on behavioral intention via cognitions. Mayfield et al. [50] mentioned that behavioral intentions, representing an individual's readiness to be engaged in a particular behavior, are cognitive in nature. However, empirical studies of Mayfield et al. [50] only presented the effects of personality types, including openness, conscientiousness and risk aversion, on short-term and long-term investment intentions respectively. Whether investment intentions are affected by attitude, subjective norm and a perceived sense of behavioral control has not been well discovered. Wu and Chen [55] extended TPB and indicated that the effects of attitudes, subjective norms and perceptual behavior control on behavioral intention are varied in different groups divided by individuals' personality traits, which called for further investigation. Personality traits, intrinsic characteristics of a person, could be the antecedents of perceptive constructs in predicting an individual's behavioral intention. For instance, people who are on good terms with others may be easily affected by peers' opinions regarding stock investment. A person who is cheerful would feel that stock investment is enjoyable. A conscientious individual would always think that he or she has insufficient time or information for stock investment. Therefore, according to extended TPB [56], which adds external factors to comprehensively explain the formation of the intentions of individuals to invest in stock markets, this study proposes that personality traits, which include agreeableness, extroversion, conscientiousness, openness to experience, and neuroticism, affect subjective norm, attitude toward stock investment, and perceived behavioral control, which in turn influence the stock investment intentions of individuals. Accordingly, the following hypotheses are proposed.

Hypotheses 5-1 (H5-1) to 5-5 (H5-5). Personality traits affect subjective norm among individuals in forming their intentions of stock investment.

Hypotheses 6-1 (H6-1) to 6-5 (H6-5). Personality traits affect the attitudes of individuals toward stock investment in influencing their stock investment intentions.

Hypotheses 7-1 (H7-1) to 7-5 (H7-5). Personality traits affect the perceived behavioral control among individuals in forming their intentions of stock investment.

\subsection{Moderating Roles of Gender, Age, and Experience}

Barber and Odean [57] split their sample into men and women, assuming that men were overconfident and found that male investors underperformed compared with female investors as a consequence of excessive trading. Meanwhile, gender did not account for differences in actual portfolio choices for investors [58]. Effort expectancy has been a strong factor of the intention of individuals for women and for elderly workers $[59,60]$. Women tended to be sensitive to the opinions of others; thus, social influence was salient for women [61], and their experiences decreased such influences [62]. Morris and Venkatesh [59] indicated that elderly workers were probable to be more salient to social influences, and influences decreased with experience. Moores and Chang [62] showed that significant differences were identified in the ethical decision-making process on the bases of age, whereas simply limited variances exist based on gender. Venkatesh, Thong, and Xu [63] identified that age, gender, and experience moderated the effect of hedonic motivation on behavioral intention... Therefore, this study proposes the following: 
Hypothesis 8 (H8). Gender moderates the relationships among the personality, perceptive factors, and stock investment intentions of individuals.

Hypothesis 9 (H9). Age moderates the relationships among the personality, perceptive factors, and stock investment intentions of individuals.

Hypothesis 10 (H10). Experience moderates the relationships among the personality, perceptive factors, and stock investment intentions of individuals.

Figure 2 presents the research conceptual model combining the big five inventories of personality and the three main dimensions of TPB as the antecedent factors in affecting the stock investment intentions of individuals.

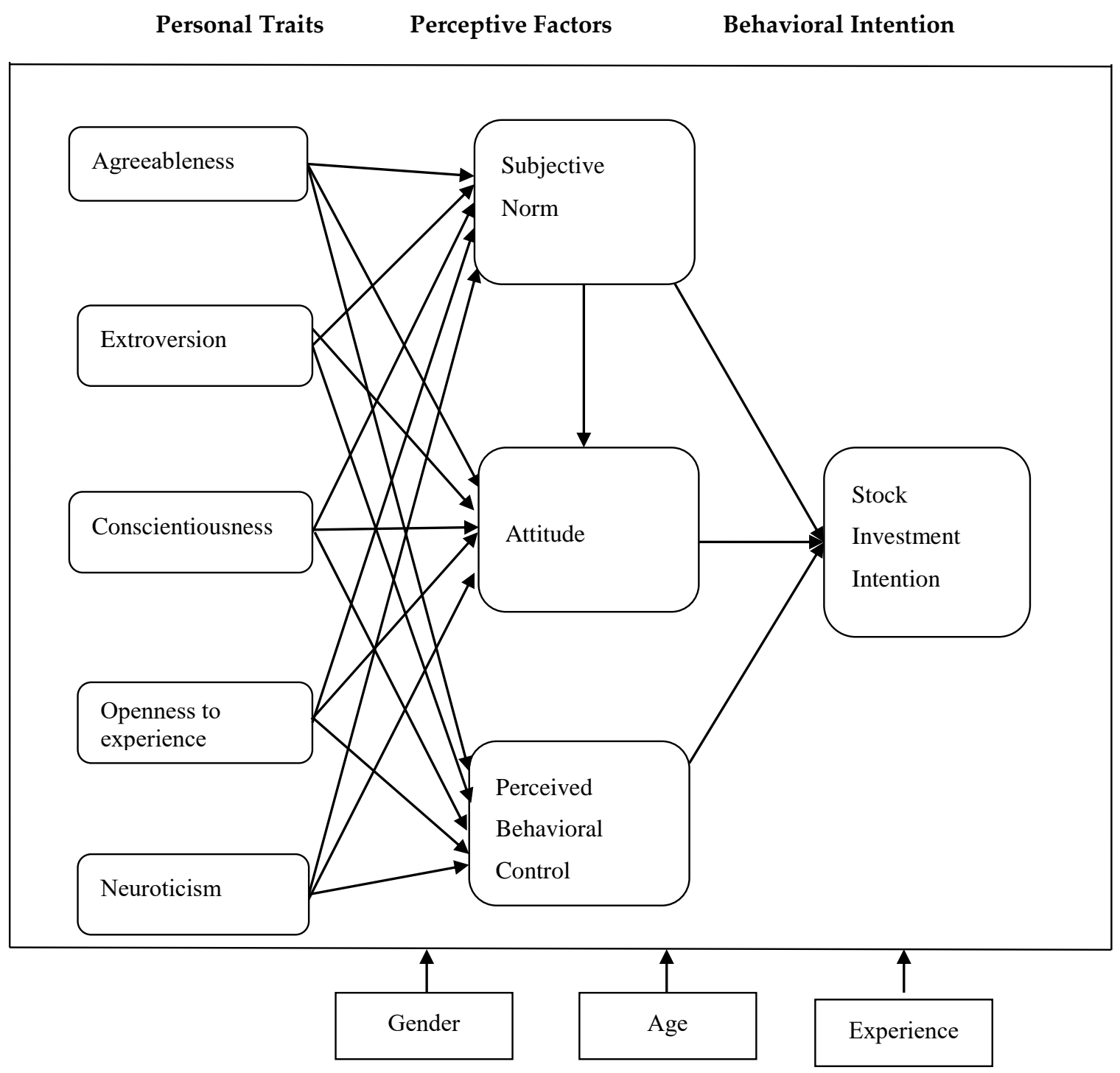

Figure 2. Conceptual framework of stock investment intention.

\section{Research Methods}

\subsection{Sample and Data Collection}

The target population for this study and administration of the questionnaire were individuals who were 20 years old and above, eligible to have direct trading in stock markets in Taiwan, had income from 
salary or investment, and might or might not have prior stock market investing experiences. Keller and Siegrist [64] observed that stock investing was a topic with wide media exposure and thus the majority of individuals had formed attitudes regarding stock investment even if they might not have been active investors in stock markets. Using the approach of cross-sectional studies, the participants were sampled proportionate on the basis of geographic disbursement, as well age, gender, and trading experience distributions. The questionnaires with stamped envelopes were sent to the participants via phone or e-mail to obtain their approval. Thereafter, information regarding the purpose of the study and the instructions was provided. The author invited the participants were to distribute the questionnaires randomly to their coworkers who were the target sample by addressing that participating in answering the questionnaire was voluntary with all the responses treated confidentially and anonymously. The main survey was distributed to 480 subjects, in which 390 questionnaires were collected with five incomplete responses. Finally, 385 valid responses were obtained, reaching an effective response rate of $80.21 \%$.

\subsection{Research Instruments}

The first part of the research survey addressed the purpose of the research and instructions for filling out the questionnaires were presented. The second part was designed for respondents to provide their demographic information. The third part was the research instrument with items using a five-point (1-5) Likert scale, in which 1 indicated "strongly disagree" and 5 indicated "strongly agree." This study measured the main cognitive constructs in TPB on the basis of Elliot and Ainsworth [31] and revised the items to fit the context and language in Taiwan according to Lee, Koo, $\mathrm{Wu}$, and $\mathrm{Yu}$ [65]. The items to measure subjective norm included "I will participate in stock investment if the superior management agrees," "I will participate in stock investment if my colleagues do," "I will participate in stock investment if the media promotes it," and "I will participate in stock investment if the government and experts encourage it." The measures of the attitude toward stock investment were produced by asking about the instrumental and affective attitudes of the individuals. The measuring items e of perceived behavioral control was acquired by a single semantic distinctive scale that the perceived ease or difficulty of behavioral performance is measured [31]. Four items were used to measure the intention of stock investment, including "Do you plan to invest in the stock market?" "I will strongly recommend others to invest in the stock market," "I will continue to invest in the stock market," and "I can stand the inconvenience caused in stock investment" [65]. The big five-factor model is among the widely used models for personality research [66]. Studies of personality traits, including neuroticism, extroversion, openness, agreeableness, and conscientiousness, have been investigated in various ages, cultures, and environments [67]. The measuring items of personality traits in this study were adapted from the NEO Five-Factor Inventory (NEO-FFI) [50,68]. Neuman [69] suggested that precise expression and straight-forward wordings should be adopted to get valid responses. Teng, Tseng, Li, and Yu [70] argued that a shortened version of the big five-personality scale can reduce research cost, increase participants, and make the administration of survey convenient. This study conducted a pretest for detecting ambiguity of the questions and scale format by inviting two practitioners in the stock market, with more than 20 years of experience, and one financial academic scholar to provide opinions for the improvement of the research instrument. For instance, highlights were added before each question to have better layout in the research survey. This study also conducted an empirical pilot study among 100 participants by distributing the draft research instrument to the target sample. A total of 82 responses were gathered in the pilot study, with a response rate of $82 \%$. Exploratory factor analyses (EFA) were used to assess the unidimensionality. The tentative measuring items of personality traits were examined via $t$-test and condensed to 35 items. This study employed the reliability tests for data analysis of the data of pilot study, and the results indicated that the analyses regarding the constructs' internal consistencies were satisfactory. 


\section{Results}

\subsection{Demographic Information}

Table 1 summarizes the respondents' demographic information in the main survey. A total of $38.18 \%$ were in the age group of 21 to $30,26.23 \%$ were 31 to $40,22.08 \%$ were 41 to 50 , and $10.65 \%$ were 51 to 60 . Most of the respondents have an educational background of bachelor's degree (47.27\%), followed by technical school (28.83\%). A total of $46.75 \%$ of the respondents had trading experiences in the stock market, and $53.25 \%$ had not participated in stock trading yet.

Table 1. Demographic profile of respondents.

\begin{tabular}{|c|c|c|}
\hline Characteristic & Frequency & Percentage \\
\hline \multicolumn{3}{|l|}{ Gender } \\
\hline Male & 164 & $42.60 \%$ \\
\hline Female & 221 & $57.40 \%$ \\
\hline \multicolumn{3}{|l|}{ Age } \\
\hline 20 or below & 8 & $2.08 \%$ \\
\hline 21-30 & 147 & $38.18 \%$ \\
\hline $31-40$ & 101 & $26.23 \%$ \\
\hline $41-50$ & 85 & $22.08 \%$ \\
\hline $51-60$ & 41 & $10.65 \%$ \\
\hline 61 or above & 3 & $0.78 \%$ \\
\hline \multicolumn{3}{|l|}{ Education } \\
\hline High school or equivalent & 77 & $20.00 \%$ \\
\hline Technical school & 111 & $28.83 \%$ \\
\hline Tertiary & 182 & $47.27 \%$ \\
\hline Master's degree or above & 15 & $3.90 \%$ \\
\hline \multicolumn{3}{|l|}{ Marital status } \\
\hline Married & 187 & $48.57 \%$ \\
\hline Single & 198 & $51.43 \%$ \\
\hline \multicolumn{3}{|l|}{ Seniority } \\
\hline Less than 1 years & 75 & $19.48 \%$ \\
\hline $1+$ to 2 years & 49 & $12.73 \%$ \\
\hline $2+$ to 5 years & 88 & $22.86 \%$ \\
\hline $5+$ to 10 years & 77 & $20.00 \%$ \\
\hline $10+$ to 20 years & 65 & $16.88 \%$ \\
\hline More than 20 years & 31 & $8.05 \%$ \\
\hline \multicolumn{3}{|l|}{ Job title } \\
\hline Entry level & 198 & $51.43 \%$ \\
\hline Associate & 75 & $19.48 \%$ \\
\hline Director & 53 & $13.77 \%$ \\
\hline Manager & 59 & $15.32 \%$ \\
\hline \multicolumn{3}{|l|}{ Trading experience } \\
\hline Yes & 180 & $46.75 \%$ \\
\hline No & 205 & $53.25 \%$ \\
\hline
\end{tabular}

\subsection{Data Analysis via Partial Least Squares Structural Equation Modeling}

This study analyzes the survey data via partial least squares structural equation modeling (PLS-SEM) techniques by using SmartPLS 3. PLS-SEM has been widely applied in management and information systems and reported to provide robust analyses in the areas of banking and finance [71]. PLS-SEM is a non-parametric method maximizing the variance explained in latent constructs, which are directly unobservable phenomena. Avkiran and Ringle [71] indicated that behavioral finance provides great opportunities for utilizing PLS-SEM techniques. Compared with the covariance-based SEM (COV-SEM), PLS-SEM places fewer requirements on residual distributions, measuring scales and sample sizes [72]. PLS-SEM is suitable in the research that the measures have not been well recognized or used in a new measurement [73]. There has been little research presenting a model with associated 
variables to measure the perceptive constructs, including subjective norm, attitude toward stock investment, and perceive behavioral control for investigating the stock investment intentions of individuals. Therefore, PLS-SEM is considered appropriate for analyzing the comprehensive research model that is proposed as an estimate model combining related theories and empirical studies.

\subsubsection{Assessment of Measurement Properties}

The measurement model is evaluated by analyzing item reliability, internal consistency, and discriminant validity [74]. The individual item reliability is examined using the values of item loadings, i.e., correlations of the measures with their respective construct. This study eliminates items with loadings of less than 0.6 to improve the item reliabilities for additional model analyses [75]. Table 2 shows the 34 indicators' item loadings in the measurement model.

Table 2. Standard loadings of measurements.

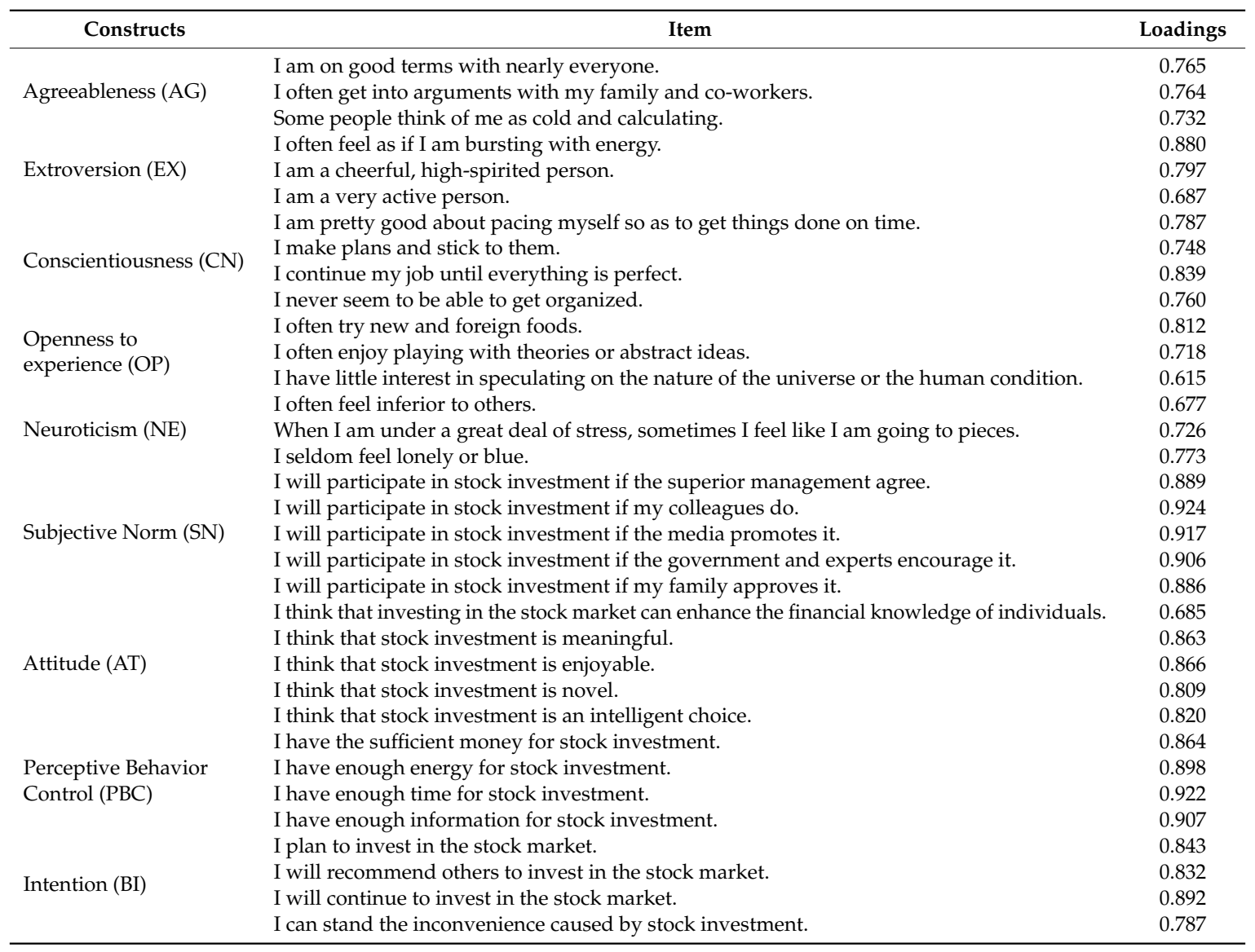

Note: This table presents the loadings of the indicator items. An indicator loading value greater than 0.6 shows that the indicator reliability is accepted [75].

The latent constructs' internal consistencies are analyzed by having composite reliability with value higher than 0.7 and the average variance extracted (AVE) above 0.5 [76]. Table 3 shows that the composite reliability values of all the constructs exceed the threshold of 0.7 , indicating their internal consistency reliability [77], and all constructs exhibit an AVE value in excess of the cut-off value level of 0.5 for their convergent validity. 
Table 3. Internal consistency.

\begin{tabular}{ccc}
\hline Constructs & Composite Reliability (CR) & AVE \\
\hline AG & 0.798 & 0.568 \\
EX & 0.905 & 0.658 \\
CN & 0.905 & 0.704 \\
OP & 0.865 & 0.615 \\
NE & 0.833 & 0.627 \\
SN & 0.769 & 0.527 \\
AT & 0.761 & 0.518 \\
PBC & 0.943 & 0.807 \\
BI & 0.957 & 0.818 \\
\hline
\end{tabular}

Note: This table reports the values of $C R$, which are higher than 0.7 , indicating that the internal consistency is satisfactory $[71,74]$. The AVE value greater than 0.5 represents the convergent validity $[76,78]$.

Discriminant validity evaluates the extent to which a construct is different from others [74]. In the measurement model, a given construct is suggested to have more variance with its measures than it shares with other constructs $[78,79]$. Table 4 reports the matrix of correlation and the results of discriminant validity analyses are acceptable.

Table 4. Discriminant validity of constructs.

\begin{tabular}{cccccccccc}
\hline Constructs & AG & EX & CN & OP & NE & SN & AT & PBC & BI \\
\hline AG & 0.754 & & & & & & & & \\
EX & 0.539 & 0.792 & & & & & & & \\
CN & 0.575 & 0.666 & 0.784 & & & & & & \\
OP & 0.415 & 0.475 & 0.499 & 0.720 & & & & & \\
NE & -0.368 & -0.426 & -0.443 & -0.205 & 0.726 & & & & \\
SN & -0.003 & 0.111 & 0.126 & 0.189 & -0.021 & 0.905 & & & \\
AT & 0.197 & 0.272 & 0.277 & 0.279 & -0.209 & 0.564 & 0.811 & & \\
PBC & 0.064 & 0.252 & 0.278 & 0.236 & -0.12 & 0.606 & 0.501 & 0.898 & \\
BI & 0.094 & 0.209 & 0.191 & 0.237 & -0.147 & 0.719 & 0.724 & 0.595 & 0.839 \\
\hline
\end{tabular}

Note: This table presents the square root of AVE value for each construct and its correlations with other constructs. The diagonal shows the square root of AVE values. The non-diagonal elements represent the correlations of a construct with other constructs. According to [76], discriminant validity is met [76].

\subsubsection{Analysis of the Structural Model}

Figure 3 shows the partial least squares (PLS) analysis results with standardized path coefficients and $\mathrm{R}^{2}$ values in the research model. Utilizing the bootstrapping techniques with a test similar to the traditional $t$-test, the results can be applied to explain the significance among the paths of constructs in the structural model [74]. The empirical results using SmartPLS 3.0 are shown in Figures 3 and 4. Table 5 summarizes the path coefficients and $t$-statistic results via bootstrapping with 5000 resamples.

\subsubsection{Goodness of Fit}

The goodness of fit (GoF) index is suggested as the geometric mean of the average $\mathrm{R}^{2}$ and average communality of all endogenous constructs [80]. Wetzels et al. [81] proposed that communality equals AVE in the PLS path modeling approach and the GoF criteria are as follows. GoFsmall =0.1, GoF medium $=0.25$, and GoF Large $=0.36$. These criteria are the baselines for verifying the validity of the PLS path model. The GoF value obtained in this study is 0.45 , which exceeds the cut-off value of 0.36 for a substantial model and shows that this research model performs better compared with the baseline values. 


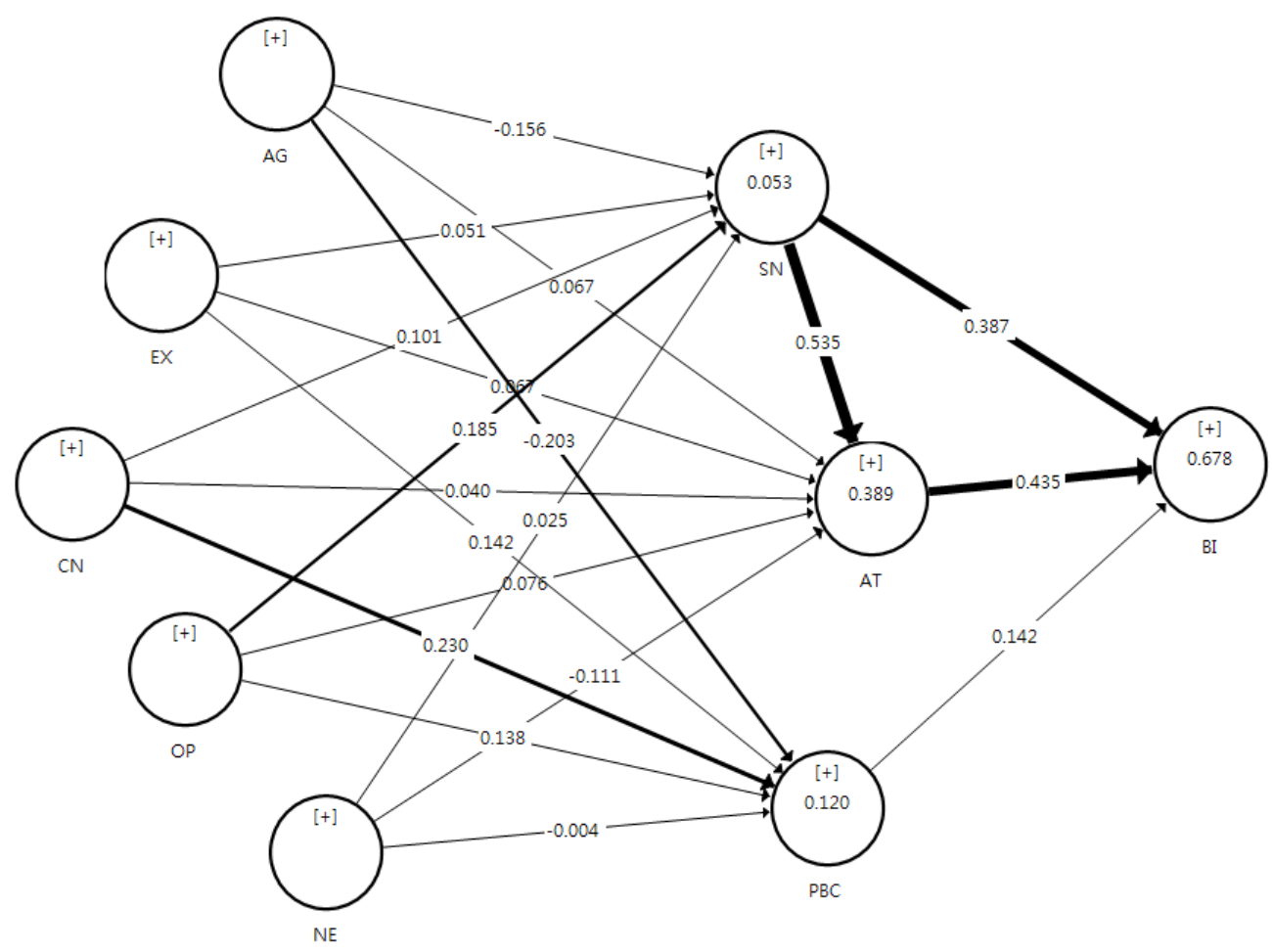

Figure 3. Full model with path coefficients. Note: the path coefficients are highlighted with thick lines representing strong relationships and thin lines for small path coefficients.

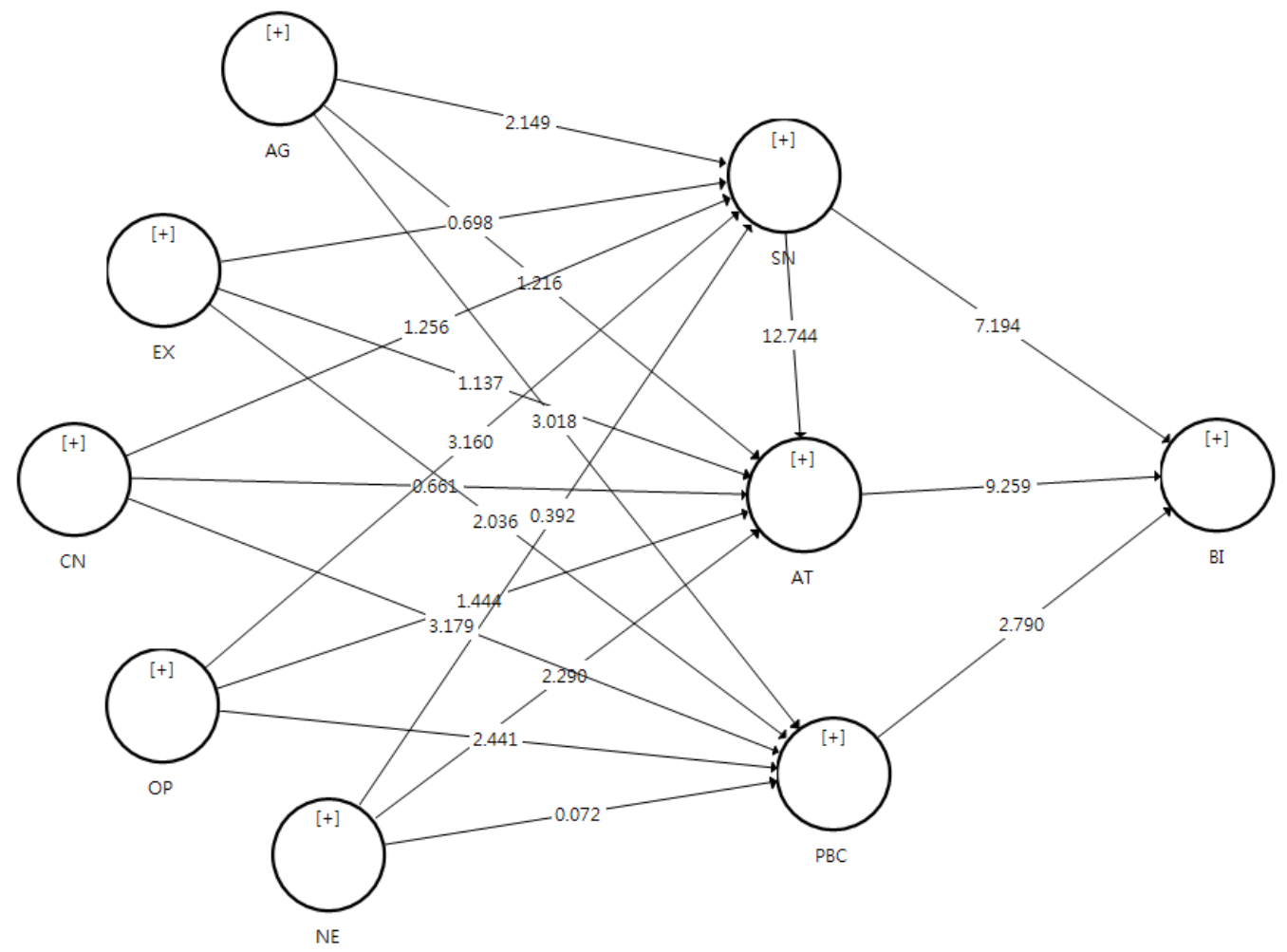

Figure 4. PLS analysis of the structural model with $t$-value. Note: This figure presents the results of the $t$-test for the structural model via SmartPLS 3.0. 
Table 5. Results of hypothesis testing.

\begin{tabular}{ccccc}
\hline \multicolumn{2}{c}{ Hypothesis } & Path Coefficients & $\boldsymbol{t}$-Value & $p$-Value \\
\hline H1 & $\mathrm{SN} \rightarrow \mathrm{BI}$ & 0.387 & $7.194^{* * *}$ & 0.000 \\
$\mathrm{H} 2$ & $\mathrm{AT} \rightarrow \mathrm{BI}$ & 0.435 & $9.259^{* * *}$ & 0.000 \\
$\mathrm{H} 3$ & $\mathrm{PBC} \rightarrow \mathrm{BI}$ & 0.142 & $2.790^{* * *}$ & 0.005 \\
$\mathrm{H} 4$ & $\mathrm{SN} \rightarrow \mathrm{AT}$ & 0.535 & $12.744^{* * *}$ & 0.000 \\
$\mathrm{H} 5-1$ & $\mathrm{AG} \rightarrow \mathrm{SN}$ & -0.156 & $2.149^{* *}$ & 0.032 \\
$\mathrm{H} 5-2$ & $\mathrm{EX} \rightarrow \mathrm{SN}$ & 0.051 & 0.698 & 0.485 \\
$\mathrm{H} 5-3$ & $\mathrm{CN} \rightarrow \mathrm{SN}$ & 0.101 & 1.256 & 0.209 \\
$\mathrm{H} 5-4$ & $\mathrm{OP} \rightarrow \mathrm{SN}$ & 0.185 & $3.160^{* * *}$ & 0.002 \\
$\mathrm{H} 5-5$ & $\mathrm{NE} \rightarrow \mathrm{SN}$ & 0.025 & 0.392 & 0.695 \\
$\mathrm{H} 6-1$ & $\mathrm{AG} \rightarrow \mathrm{AT}$ & 0.067 & 1.216 & 0.224 \\
$\mathrm{H} 6-2$ & $\mathrm{EX} \rightarrow \mathrm{AT}$ & 0.067 & 1.137 & 0.255 \\
$\mathrm{H} 6-3$ & $\mathrm{CN} \rightarrow \mathrm{AT}$ & 0.040 & 0.661 & 0.509 \\
$\mathrm{H} 6-4$ & $\mathrm{OP} \rightarrow \mathrm{AT}$ & 0.067 & 1.444 & 0.149 \\
$\mathrm{H} 6-5$ & $\mathrm{NE} \rightarrow \mathrm{AT}$ & -0.111 & $2.290^{* *}$ & 0.022 \\
$\mathrm{H} 7-1$ & $\mathrm{AG} \rightarrow \mathrm{PBC}$ & -0.203 & $3.018^{* * *}$ & 0.003 \\
$\mathrm{H} 7-2$ & $\mathrm{EX} \rightarrow \mathrm{PBC}$ & 0.142 & $2.036^{* *}$ & 0.042 \\
$\mathrm{H} 7-3$ & $\mathrm{CN} \rightarrow \mathrm{PBC}$ & 0.230 & $3.179^{* * *}$ & 0.001 \\
$\mathrm{H} 7-4$ & $\mathrm{OP} \rightarrow \mathrm{PBC}$ & 0.138 & $2.441^{* *}$ & 0.015 \\
$\mathrm{H} 7-5$ & $\mathrm{NE} \rightarrow \mathrm{PBC}$ & -0.004 & 0.072 & 0.943 \\
\hline
\end{tabular}

Note: This table reports the hypothesis testing results in the structural model. The results support the research hypotheses that $\mathrm{SN}, \mathrm{AT}$, and $\mathrm{PBC}$ are positively related to $\mathrm{BI}(\mathrm{H} 1, \mathrm{H} 2$, and $\mathrm{H} 3)$, and $\mathrm{SN}$ is positively associated with AT (H4). Furthermore, AG and OP are related to ST significantly (H5-1 and H5-4). NT is negatively associated with AT (H6-5). AG, EX, CN, and OP are shown to be related to PBC significantly (H7-1, H7-2, H7-3, and H7-4). ***, **, and * represent significant levels at $1 \%, 5 \%$, and $10 \%$ (two-tailed test).

\subsubsection{Hypothesis Testing}

Table 5 indicates that the four hypotheses proposed according to TPB (H1 to $\mathrm{H} 4)$ are all supported. $\mathrm{SN}, \mathrm{AT}$, and PBC have significant and positive impacts on BI (H1: $\gamma=0.387, t=7.194, p<0.01 ; \mathrm{H} 2$ : $\gamma=0.435, t=9.259, p<0.01$; H3: $\gamma=0.142, t=2.790, p<0.01)$. SN is also shown to have a significant and positive impact on AT (H4: $\gamma=0.535, t=12.744, p<0.01)$. As to the effects of personality traits on the perceptive factors, AG has a significant and negative effect on SN (H5-1: $\gamma=-0.156, t=2.149$, $p<0.05)$, while OP has a significant and positive effect on SN (H5-4: $\gamma=0.185, t=3.160, p<0.01)$. The empirical results reveal that NE has a significant and negative effect on AT (H6-5: $\gamma=-0.111$, $t=2.290, p<0.05)$. AG has a significant and negative effect on PBC (H7-1: $\gamma=-0.203, t=3.018$, $p<0.01)$. EX, CN, and OP have significant and positive effects on PBC (H7-2: $\gamma=0.142, t=2.036$, $p<0.05$; H7-3: $\gamma=0.230, t=3.179, p<0.01$; H7-4: $\gamma=0.138, t=2.441, p<0.05)$. To test the hypotheses from $\mathrm{H} 8$ to H10, this study utilizes partial least squares multi-group analysis (PLS-MGA).

\subsubsection{Partial Least Squares Multi-Group Analysis}

Sarstedt et al. [82] proposed PLS-MGA as a novel approach for group comparisons in research. PLS-MGA serves as a test of non-parametric significance for examining the difference of group-specific effects based on PLS-SEM bootstrapping techniques [83]. The moderating effects of gender, age, and experience are analyzed via PLS-MGA by using SmartPLS 3. The author divides the age categories into 40 and over 41 subsamples in considering the interpretable categories and compensation for the unequal age distribution in the sample [62]. The experience categories are divided into two subsamples of having stock trading experiences and no stock trading experiences. The results of PLS-MGA are summarized in Table 6. The differences between the path coefficients of the male group and those of the female group are not significant, except for the relationship between $\mathrm{CN}$ and AT. The significant difference between the path coefficients of the old group (over 41) and those of the young group (up to 40) is only found in the relationship between EX and PBC. Interestingly, stock trading experiences play significant moderating roles in four relationships, including those between AT and BI, EX and SN, EX and AT, and ET and PBC. Consequently, H8 to H10 are partly supported. 
Table 6. Results of PLS-MGA.

\begin{tabular}{|c|c|c|c|c|c|c|c|c|c|c|}
\hline \multicolumn{2}{|c|}{ Hypothesis } & \multicolumn{2}{|c|}{ Standardized Path Coefficients } & \multirow{2}{*}{$\begin{array}{c}\text { Gender } \\
\text { Difference }\end{array}$} & \multicolumn{2}{|c|}{ Standardized Path Coefficients } & \multirow{2}{*}{$\begin{array}{c}\text { Age } \\
\text { Difference }\end{array}$} & \multicolumn{2}{|c|}{ Standardized Path Coefficients } & \multirow{2}{*}{$\begin{array}{l}\text { Experience } \\
\text { Difference }\end{array}$} \\
\hline & othesis & Male & Female & & Old & Young & & $\begin{array}{c}\text { Have Trading } \\
\text { Experience }\end{array}$ & $\begin{array}{l}\text { No Trading } \\
\text { Experience }\end{array}$ & \\
\hline $\mathrm{H} 1$ & $\mathrm{SN} \rightarrow \mathrm{BI}$ & 0.386 & 0.388 & 0.508 & 0.471 & 0.36 & 0.168 & 0.388 & 0.420 & 0.616 \\
\hline $\mathrm{H} 2$ & $\mathrm{AT} \rightarrow \mathrm{BI}$ & 0.440 & 0.432 & 0.462 & 0.254 & 0.493 & 0.992 & 0.495 & 0.371 & $0.090 *$ \\
\hline H3 & $\mathrm{PBC} \rightarrow \mathrm{BI}$ & 0.130 & 0.155 & 0.590 & 0.222 & 0.120 & 0.190 & 0.095 & 0.138 & 0.667 \\
\hline $\mathrm{H} 4$ & $\mathrm{SN} \rightarrow \mathrm{AT}$ & 0.538 & 0.520 & 0.419 & 0.553 & 0.526 & 0.377 & 0.560 & 0.489 & 0.193 \\
\hline H5-1 & $\mathrm{AG} \rightarrow \mathrm{SN}$ & -0.088 & -0.179 & 0.271 & -0.101 & -0.195 & 0.271 & -0.020 & -0.057 & 0.404 \\
\hline H5-2 & $\mathrm{EX} \rightarrow \mathrm{SN}$ & -0.008 & 0.067 & 0.678 & 0.131 & -0.024 & 0.158 & 0.132 & -0.080 & $0.085 *$ \\
\hline H5-3 & $\mathrm{CN} \rightarrow \mathrm{SN}$ & 0.094 & 0.114 & 0.541 & 0.050 & 0.134 & 0.707 & -0.041 & 0.129 & 0.862 \\
\hline H5-4 & $\mathrm{OP} \rightarrow \mathrm{SN}$ & 0.051 & 0.240 & 0.880 & 0.288 & 0.154 & 0.137 & 0.116 & 0.238 & 0.858 \\
\hline H5-5 & $\mathrm{NE} \rightarrow \mathrm{SN}$ & -0.055 & 0.026 & 0.705 & 0.102 & -0.037 & 0.235 & 0.030 & 0.012 & 0.464 \\
\hline H6-1 & $\mathrm{AG} \rightarrow \mathrm{AT}$ & 0.044 & 0.077 & 0.610 & 0.017 & 0.103 & 0.776 & 0.099 & 0.062 & 0.378 \\
\hline H6-2 & $\mathrm{EX} \rightarrow \mathrm{AT}$ & -0.018 & 0.081 & 0.796 & 0.005 & 0.072 & 0.713 & 0.160 & -0.035 & $0.046^{* *}$ \\
\hline H6-3 & $\mathrm{CN} \rightarrow \mathrm{AT}$ & 0.237 & -0.060 & $0.008^{* *}$ & 0.080 & 0.058 & 0.430 & -0.079 & 0.138 & 0.963 \\
\hline H6-4 & $\mathrm{OP} \rightarrow \mathrm{AT}$ & -0.004 & 0.132 & 0.889 & 0.095 & 0.033 & 0.286 & 0.098 & 0.042 & 0.299 \\
\hline H6-5 & $\mathrm{NE} \rightarrow \mathrm{AT}$ & -0.064 & -0.205 & 0.120 & 0.051 & -0.135 & 0.101 & -0.049 & -0.167 & 0.119 \\
\hline H7-1 & $\mathrm{AG} \rightarrow \mathrm{PBC}$ & -0.191 & -0.191 & 0.514 & -0.199 & -0.194 & 0.522 & -0.082 & -0.119 & 0.407 \\
\hline H7-2 & $\mathrm{EX} \rightarrow \mathrm{PBC}$ & 0.031 & 0.202 & 0.839 & 0.325 & 0.023 & $0.018^{* *}$ & 0.246 & 0.017 & 0.057 * \\
\hline H7-3 & $\mathrm{CN} \rightarrow \mathrm{PBC}$ & 0.261 & 0.235 & 0.435 & 0.158 & 0.298 & 0.842 & 0.055 & 0.212 & 0.869 \\
\hline H7-4 & $\mathrm{OP} \rightarrow \mathrm{PBC}$ & 0.083 & 0.154 & 0.663 & 0.181 & 0.103 & 0.244 & 0.145 & 0.133 & 0.462 \\
\hline H7-5 & $\mathrm{NE} \rightarrow \mathrm{PBC}$ & 0.045 & -0.046 & 0.252 & -0.026 & -0.023 & 0.512 & 0.011 & 0.012 & 0.520 \\
\hline
\end{tabular}

Note: This table reports the hypothesis testing results on the moderating effects of gender, age, and experience. The findings reveal that gender only plays a moderating role on the relationship between $\mathrm{CN}$ and $\mathrm{AT}$, and age has a moderating effect on the relationship between EX and PBC. Stock trading experiences have significant moderating effects on relationships between AT and BI, among EX, SN, and AT, and between EX and PBC. H8 to H10 are partly supported. ** and * represent significant levels at 5\% and 10\% (two-tailed test) [82] 


\section{Conclusions and Implications}

The primary topics in traditional finance include classical decision theory, rational behavior, risk aversion, model portfolio theory (MPT), CAPM, and EMH, which have been the leading paradigms for decades, suggesting that investors make choices rationally and thus maximize utility. However, empirical evidence has shown that the assumptions related to traditional finance are not supported [84]. The research of behavioral finance initiated to observe investors' behaviors to propose models describing how investors make decisions in investment. Behavioral finance incorporates the concepts of social sciences in understanding the investors' behaviors. Nonetheless, previous topics in behavioral finance have been widely discussed regarding behavioral decision theory, prospect theory, overconfidence, herding, and disposition effects. The issues of the intentions of individual investors for stock investment have not been investigated well. This study provides the theoretical bases and empirical evidence to capture the stock investment intentions of the individuals, including those who participated in the stock market and those were not involved in the stock market yet, through their personality characters, attitudes, and cognitions.

To the best of the author's knowledge, the current study is the first to show the linkages among the personality traits and perceptions of individual investors and their impacts on stock investment intentions. In contrast with previous studies that have investigated the impact of personality traits on investment choices and outcomes, which have been conducted on the basis of experimental or clinical designs with samples from undergraduate business [28] and college student investors enrolled in a core finance unit (i.e., investment analysis) [27], the current study collects data from 385 individuals who are more than 20 years old and eligible to participate in stock markets in Taiwan, including those with and without stock-trading experiences. The contributions of these results to the literature are numerous. First, this study provides evidence with empirical surveys to revalidate TPB in explaining the intentions of individuals to participate in stock investment. Subjective norm, attitude towards stock investment, and perceived behavioral control are all revealed to significantly influence the stock investment intention of an individual. Subjective norm is an individual's perceived social pressure to perform or not to perform the behavior according to the opinion about what important others believe the individual should do. Individuals are inclined to conduct a behavior if the key person or organization encourages such a behavior. Therefore, having more media to report information about the facilities for stock investment and government policies to encourage stock investment will increase individuals' intention to participate in the stock-investing activities. The attitudinal factor (e.g., the feelings that investing in the stock market can enhance the financial knowledge of individuals and is meaningful, enjoyable, and novel) is proved to affect individual intentions for stock investment. Hence, security firms can develop additional investment tools, such as mobile applications (Apps), financial analysis software, and online investment services, in which innovative investment portfolio techniques and knowledge are provided. Perceived behavioral control refers to individuals' perceptions of their ability to perform stock-trading activities in this study. The government can improve the investment environments with transparent corporate information and fair-trading mechanisms. Security practitioners should improve the efficiency of infrastructure and technology systems to reduce individual investors' time in stock trading. Providing individuals with accurate information in making investment decisions and simplified approaches to invest in stock markets will increase individuals' intentions in stock investment. The empirical results also indicate that subjective norm has significant effects on attitude, implying that, if individuals' peers or colleagues also invest in stock markets, their feelings about stock investment will be more positive.

Second, extending TPB with the big five personality traits, this study discovers that openness to experience and agreeableness significantly affect subjective norm. As expected, an individual with a preference for variety and intellectual curiosity (i.e., openness) is likely to be affected in forming his or her perceptions regarding social pressure from others. However, surprisingly, the impact of agreeableness on subjective norm is found to be significant and negative. The possible explanations could be that individuals who show personal warmth and cooperation with others still have their own 
opinions and less attention is paid to the peer influences regarding stock investment. Neuroticism is shown to affect an individual's attitude toward stock investment significantly and negatively. For people who always feel inferior to others, anxious, and insecure tend to ascertain that stock investment is harmful and that people will lose money in stock trading. This finding would provide practical implications for the security practitioners that persuading anxious individuals to invest in the stock market would be difficult. Besides, agreeableness is identified to influence perceived behavioral control significantly and negatively. The findings reveal that individuals with agreeable personality may spend their money, time and energy in maintaining relationships with others and thus less control for performing stock trading is perceived. The effects of extroversion, conscientiousness and openness to experience on subjective norm are significant and positive. Accordingly, the security practitioners could attempt to search for persons who are cheerful and extroverted, strong-willed and conscientious, or individuals who are open to new things and ideas, because these individuals may have more time, energy, or money for participating in stock investment.

Third, the author utilizes the PLS-MGA techniques to unearth whether gender, age, and experience plays moderating roles in influencing the investment intentions of the individuals via their perceptions. Mayfield et al. [50] reported that males have additional intentionality to make short-term and long-term investments and that individuals with great previous experience in financial investment tend to have higher intentions to make short-term investments. The empirical results of this study find that gender only has a significant effect on the linkage between conscientiousness and attitude and that age has a significant effect on the relationship between extroversion and perceived behavioral control. For conscientious individuals, men are more likely to be affected in forming their attitudes (i.e., opinions regarding whether stock investment is good or bad), compared with women. For extroverted people who are energetic, older individuals would perceive more ability for stock trading than younger ones. This study also ascertains that prior stock trading experiences have significant effects on the relationships between attitude and stock investment intention, as well as on the linkages between extroversion and subjective norm, attitude, and perceived behavioral control. Therefore, the government and security firms should make more effort to restore confidence among individual investors, particularly those who used to be active in the stock market, to form better attitudes towards stock investment and thus be willing to get back to the stock market. The security practitioners may promote several activities, such as marathon and charity events, to attract the customers who are energetic and active, particularly those having stock trading experiences, in order to enhance their recognition of stock investment which, in turn, affects their intentions to invest in stock markets.

Consequently, when these implications are incorporated into the initiatives of security firms and government in promoting stock market participation, the perceptions and attitudes toward stock investment will be enhanced. These initiatives will facilitate low-cost financing for firms, thereby leading to sustainable development.

\section{Limitations and Directions for Future Research}

The conclusions from this study may not be of universal application because it was administered in Taiwan, with the respondents collected from the individuals who are more than 20 years old and have income from salary or investment, including those with and without stock trading experiences. Although the questionnaires were distributed to the participants with the goal of being proportionate in demographic background, additional empirical versification in various geographic areas and contexts, such as Asia and Western countries, would extend the applications of the current research. Moreover, the initially developed model combining the big five personality traits and TPB could serve as the base for future investigation in consumers' purchase or usage intentions of fin-tech products and services in the financial industries, including artificial intelligence (AI) investment tools and self-service banking. Future researchers may address developed analyses regarding the impacts of big five personalities and perceptive factors on other financial decision-making, such as herding, disposition effect, and ability heuristic. Finally, this study hopes to provide a deep investigation of the intentions of individuals 
to invest in stock markets, and the research model can serve as a theoretical foundation for future research in sustainable development.

Funding: This research received no external funding.

Conflicts of Interest: The author declares no conflict of interest.

\section{References}

1. Shantha, K.V.A. Individual Investors' learning behavior and its impact on their herd bias: An integrated analysis in the context of stock trading. Sustainability 2019, 11, 1448. [CrossRef]

2. Waygood, S. How do the capital markets undermine sustainable development? What can be done to correct this? J. Sustain. Financ. Investig. 2011, 1, 81-87. [CrossRef]

3. Lo, A.W. Reconciling efficient markets with behavioral finance: The adaptive markets hypothesis. J. Investig. Consult. 2005, 7, 21-44.

4. Lo, A.W. Adaptive Markets and the New World Order. Financ. Anal. J. 2012, 68, 18-29. [CrossRef]

5. Dobni, D.M.; Racine, M.D. Stock market image: The good, the bad, and the ugly. J. Behav. Financ. 2015, 16, 130-139. [CrossRef]

6. Chen, H.L.; Chow, E.H.; Shiu, C.Y. The informational role of individual investors in stock pricing: Evidence from large individual and small retail investors. Pac. Basin Financ. J. 2015, 31, 36-56. [CrossRef]

7. Barber, B.M.; Lee, Y.T.; Liu, Y.J;; Odean, T. Just how much do individual investors lose by trading? Rev. Financ. Stud. 2009, 22, 609-632. [CrossRef]

8. Taiwan Stock Exchange Corporation (TWSE) (2018). 2017 Securities Trading Values by Type of Investors, Annual Statistics. Available online: http://www.twse.com.tw/en/statistics/statisticsList?type=07\&subType= 262 (accessed on 7 August 2019).

9. Gordon, M.J. Optimal investment and financing policy. J. Financ. 1963, 18, 264-272.

10. Lan, S.; Yang, C.; Tsent, M.T. Corporate sustainability on causal financial efficiency model in a hierarchical structure under uncertainties. J. Clean. Prod. 2019, 239, 1-12. [CrossRef]

11. Money, Lies, and Scandal. Available online: https:/www.businesstoday.com.tw/article/category/80393/ post $/ 200406240032 / \%$ E9\%8C\%A2\%E2\%80\%A7\%E8\%AC\%8A\%E8\%A8\%80\%E2\%80\%A7\%E5\%A4\%A7\% E9\%BB\%91\%E5\%B9\%95\%20P.46 (accessed on 6 August 2019).

12. The Black Holes of Family Businesses. Available online: https://www.gvm.com.tw/article.html?id=11581 (accessed on 6 August 2019).

13. Sharpe, W.F. Capital asset prices: A theory of market equilibrium under conditions of risk. J. Financ. 1964, $19,425-442$.

14. Lintner, J. The valuation of risk assets and the selection of risky investments in stock portfolios and capital budgets. Rev. Econ. Stat. 1965, 47, 13-37. [CrossRef]

15. Mossin, J. Equilibrium in a capital asset market. Econometrica 1966, 34, 768-783. [CrossRef]

16. Fama, E.F. Efficient capital markets: A review of theory and empirical work source. J. Financ. 1970, 25, 383-417. [CrossRef]

17. Wang, Y.Y.; Chih, H.H.; Chou, R.K. Review of behavioral finance studies in Taiwan. Taiwan Econ. Rev. 2016, $44,1-55$.

18. Andersson, M.; Hedesström, M.; Gärling, T. A social-psychological perspective on herding in stock markets. J. Behav. Financ. 2014, 15, 226-234. [CrossRef]

19. Svedsater, H.; Karlsson, N.; Garling, T. Momentum trading, disposition effects and prediction of future share prices: An experimental study of multiple reference points in responses to short and long run return trends. Appl. Financ. Econ. 2009, 19, 595-610. [CrossRef]

20. Hoffmann, A.O.I.; Post, T.; Pennings, J.M.E. How Investor perceptions drive actual trading and risk-taking behavior. J. Behav. Financ. 2015, 16, 94-103. [CrossRef]

21. Yeh, C.C.; Li, C.A. The relationship among investor sentiment, herding and non-herding. Rev. Secur. Futures Mark. 2012, 24, 141-182.

22. Shefrin, H.; Statman, M. The disposition to sell winners too early and ride losers too long: Theory and evidence. J. Financ. 1985, 40, 777-790. [CrossRef] 
23. Barberis, N.; Xiong, W. What drives the disposition effect? An analysis of a long-standing preference-based explanation. J. Financ. 2009, 64, 751-784. [CrossRef]

24. Lee, J.S.; Yen, P.H.; Chan, K.C. Market states and disposition effect: Evidence from Taiwan mutual fund investors. Appl. Econ. 2012, 45, 1331-1342. [CrossRef]

25. Kadous, K.; Tayler, W.B.; Thayer, J.M.; Young, D. Individual characteristics and the disposition effect: The opposing effects of confidence and self-regard. J. Behav. Financ. 2014, 15, 235-250. [CrossRef]

26. Ajzen, I. The theory of planned behavior. Organ. Behav. Hum. Dec. Proc. 1991, 50, 179-211. [CrossRef]

27. Durand, R.B.; Newby, R.; Peggs, L.; Siekierka, M. Personality. J. Behav. Financ. 2013, 14, 116-133. [CrossRef]

28. Oehler, A.; Wendt, S.; Wedlich, F.; Horn, M. Investors' personality influences investment decisions: Experimental evidence on extraversion and neuroticism. J. Behav. Financ. 2018, 19, 30-48. [CrossRef]

29. Ajzen, I.; Fishbein, M. Understanding Attitudes and Predicting Social Behavior; Prentice-Hall: Upper Saddle River, NJ, USA, 1980.

30. Sheeran, P.; Trafimow, D.; Armitage, C.J. Predicting behaviour from perceived behavioural control: Tests of the accuracy assumption of the theory of planned behaviour. Brit. J. Soc. Psychol. 2003, 42, 393-420. [CrossRef] [PubMed]

31. Elliott, M.A.; Ainsworth, K. Predicting university undergraduates' binge-drinking behavior: A comparative test of the one- and two-component theories of planned behavior. Addict. Behav. 2012, 37, 92-101. [CrossRef] [PubMed]

32. Chang, T.H. The Study of Consumer's Behavior Intention for Mutual Fund through the Theory of Planned Behavior. Unpublished. Master's Thesis, National Kaohsiung First University of Science and Technology, Kaohsiung, Taiwan, 2008.

33. Yen, S.H.; Chang, Y.S.; Wu, M.C. Behavioral Intention of earnings management: The explanation of agency problem, moral development and theory of planned behavior. NTU Man. Rev. 2016, 26, 107-138.

34. Adam, A.A.; Shauki, E.R. Socially responsible investment in Malaysia: Behavioral framework in evaluating investors' decision making process. J. Clean. Prod. 2014, 80, 224-240. [CrossRef]

35. Chang, M.K. Predicting unethical behavior: A comparison of the theory of reasoned action and theory of planned behavior. J. Bus. Ethics 1998, 17, 1825-1834. [CrossRef]

36. Han, H.; Hsu, L.; Sheu, C. Application of the theory of planned behavior to green hotel choice: Testing the effect of environmental friendly activities. Tour. Manag. 2010, 31, 325-334. [CrossRef]

37. Ryu, K.; Jang, S. Intention to experience local cuisine in a travel destination: The modified theory of reasoned action. J. Hosp. Tour. Res. 2006, 30, 507-516. [CrossRef]

38. Baker, R.K.; White, K.M. Predicting adolescents' use of social networking sites from an extended theory of planned behaviour perspective. Comput. Hum. Behav. 2010, 26, 1591-1597. [CrossRef]

39. Ajzen, I. Consumer attitudes and behavior: The theory of planned behavior applied to food consumption decisions. Riv. Econ. Agrar. 2015, 70, 121-138.

40. Yakasai, A.B.M.; Wan Jusoh, W.J. Testing the theory of planned behavior in determining intention to use digital coupon among university students. Econ. Financ. 2015, 31, 186-193. [CrossRef]

41. Maichum, K.; Parichatnon, S.; Peng, K.C. Application of the extended theory of planned behavior model to investigate purchase intention of green products among Thai consumers. Sustainability 2016, 8, 1077. [CrossRef]

42. Farah, M.F. An application of the theory of planned behavior to customer switching intentions in the context of bank consolidations. Int. J. Bank Mark. 2017, 35, 147-172. [CrossRef]

43. Bolton, L.E.; Cohen, J.B.; Bloom, P.N. Does marketing products as remedies create a get out of jail free card? J. Consum. Res. 2006, 33, 71-81. [CrossRef]

44. Norman, W.T. Toward an adequate taxonomy of personality attributes: Replicated factor structure in peer nomination personality ratings. J. Abnorm. Soc. Psych. 1963, 66, 574-583. [CrossRef]

45. John, O.P.; Srivastava, S. The big five trait taxonomy: History, measurement, and theoretical perspectives. In Handbook of Personality: Theory and Research; Pervin, L.A., John, O.P., Eds.; Guilford: New York, NY, USA, 1999.

46. Ben-Shahar, D.; Golan, R. Real estate and personality. J. Behav. Exp. Econ. 2014, 53, 111-119. [CrossRef]

47. Furnham, A.; Fudge, C. The five factor model of personality and sales performance. J. Individ. Differ. 2008, 29, 11-16. [CrossRef] 
48. O'Connor, M.C.; Paunonen, S.V. Big five personality predictors of post-secondary academic performance. Pers. Indiv. Differ. 2007, 43, 971-990. [CrossRef]

49. Shafer, A.B. Mediation of the big five's effect on career decision making by life task dimensions and on money attitudes by materialism. Pers. Indiv. Differ. 2000, 28, 93-109. [CrossRef]

50. Mayfield, C.; Perdue, G.; Wooten, K. Investment management and personality type. Financ. Serv. Rev. 2008, 17, 219-236.

51. Durand, R.B.; Newby, R.; Sanghani, J. An intimate portrait of the individual investor. J. Behav. Financ. 2008, 9, 193-208. [CrossRef]

52. Chang, H.Y.; Chen, K.C.; Fang, H.K. The relationship study of mutual fund investor personality traits and investment behaviour. J. Chin. Econ. Res. 2016, 14, 51-73.

53. Pan, C.H.; Statman, M. Investor personality in investor questionnaires. J. Invest. Consult. 2013, 14, 48-56. [CrossRef]

54. Svendsen, G.B.; Johnsen, J.A.K.; Almås-Sørensen, L.; Vittersø, J. Personality and technology acceptance: The influence of personality factors on the core constructs of the technology acceptance model. Behav. Inf. Technol. 2013, 32, 323-334. [CrossRef]

55. Wu, S.I.; Chen, J.H. A study of purchase behavior toward internet bookstore by theory of planned behavior. Chin. Manag. Rev. 2006, 9, 1-23.

56. Han, H.; Kim, Y. An investigation of green hotel customers' decision formation: Developing an extended model of the theory of planned behaviour. Int. J. Hosp. Manag. 2010, 29, 659-668. [CrossRef]

57. Barber, B.M.; Odean, T. Boys will be boys: Gender, overconfidence, and common stock investment. Q. J. Econ. 2001, 116, 261-292. [CrossRef]

58. Dorn, D.; Huberman, G. Who Trades? In EFA Annual Conference Paper; Columbia University: New York, NY, USA, 2002.

59. Morris, M.G.; Venkatesh, V. Age differences in technology adoption decisions: Implications for a changing work force. Pers. Psychol. 2000, 53, 375-403. [CrossRef]

60. Venkatesh, V.; Morris, M.G. Why don't men ever stop to ask for directions? Gender, social influence, and their role in technology acceptance and usage behaviour. MIS Q. 2000, 24, 115-139. [CrossRef]

61. Venkatesh, V.; Morris, M.G.; Ackerman, P.L. A longitudinal field investigation of gender differences in individual technology adoption decision-making process. Organ. Behav. Hum. Decis. Process. 2000, 83, 33-60. [CrossRef] [PubMed]

62. Moores, T.T.; Chang, J.C.J. Ethical decision making in software piracy: Initial development and test of a four-component model. MIS Q. 2006, 30, 167-180. [CrossRef]

63. Venkatesh, V.; Thong, J.Y.L.; Xu, X. Consumer acceptance and use of information technology: Extending the unified theory of acceptance and use of technology. MIS Q. 2012, 36, 157-178. [CrossRef]

64. Keller, C.; Siegrist, M. Money attitude typology and stock investment. J. Behav. Financ. 2006, 72, 88-96. [CrossRef]

65. Lee, N.H.; Koo, T.Y.; Wu, G.S.; Yu, T.K. Construction of the behavioral tendency model of tourist in Kinmen. J. Manag. 2004, 21, 131-151.

66. Spence, R.; Owens, M.; Goodyer, I. Item response theory and validity of the NEO-FFI in adolescents. Pers. Indiv. Differ. 2012, 56, 801-807. [CrossRef]

67. De Fruyt, F.; Bolle, M.D.; McCrae, R.R.; Terracciano, A.; Costa, J.P.T. Assessing the universal structure of personality in early adolescence: The NEO-PI-R and NEO-PI-3 in 24 cultures. Assessment 2009, 16, 301-311. [CrossRef]

68. Costa, P.T.; McCrae, R.R. Professional Manual for the NEO-PI-R and NEO-FFI; Psychological Assessment Resources Inc.: Odessa, FL, USA, 1992.

69. Neuman, W.L. Research Methods: Qualitative and Quantitative Approaches, 4th ed.; Allyn and Bacon: Boston, MA, USA, 2000.

70. Teng, C.I.; Tseng, H.M.; Li, I.C.; Yu, C.S. International English Big-five mini-markers: Development of the traditional Chinese version. J. Manag. 2011, 28, 579-615.

71. Avkiran, N.K.; Christian, M.R. Partial Least Squares Structural Equation Modeling-Recent Advances in Banking and Finance; Springer: Cham, The Switzerland, 2018.

72. Monecke, A.; Leisch, F. semPLS: Structural equation modeling using partial least squares. J. Stat. Softw. 2012, 48, 1-32. [CrossRef] 
73. Gefen, D.; Straub, D.W.; Boudreau, M.C. Structural equation modeling and regression: Guidelines for research practices. Commun. Assoc. Inf. Syst. 2000, 4, 1-62. [CrossRef]

74. Barclay, D.; Higgins, C.; Thompson, R. The Partial Least Squares (PLS) approach to casual modeling: Personal computer adoption and use as an illustration. Tech. Stud. 1995, 2, 285-309.

75. Agan, Y.; Kuzey, C.; Acar, M.F.; Açıkgoz, A. The relationships between corporate social responsibility, environmental supplier development, and firm performance. J. Clean. Prod. 2016, 112, 1872-1881. [CrossRef]

76. Fornell, C.; Larcker, D.F. Evaluating structural equation models with unobservable variables and measurement error. J. Mark. Res. 1981, 18, 39-50. [CrossRef]

77. Nunnally, J.C.; Bernstein, I. Psychometric Theory; McGraw-Hill: New York, NY, USA, 1994.

78. Bagozzi, R.P.; Yi, Y. On the evaluation of structural equation models. J. Acad. Mark. Sci. 1988, 16, 74-94. [CrossRef]

79. Hulland, J. Use of Partial Least Square (PLS) in strategic management research: A review of four recent studies. Strateg. Manag. J. 1999, 20, 195-204. [CrossRef]

80. Tenenhaus, M.; Vinzi, V.E.; Chatelin, Y.M.; Lauro, C. PLS path modeling. Comput. Stat. Data Anal. 2005, 48, 159-205. [CrossRef]

81. Wetzels, M.; Odekerken-Schröder, G.; Wetzels, C.V.O. Using PLS path modeling for assessing hierarchical construct models: Guidelines and empirical illustration. MIS Q. 2009, 33, 177-195. [CrossRef]

82. Sarstedt, M.; Henseler, J.; Ringle, C.M. Multigroup analysis in partial least squares (PLS) path modeling: Alternative methods and empirical results. Adv. Int. Mark. 2011, 22, 195-218.

83. Henseler, J. PLS-MGA: A non-parametric approach to partial least squares-based multi-group analysis. In Challenges at the Interface of Data Analysis, Computer Science, and Optimization; Gaul, W.A., Geyer-Schulz, A., Schmidt-Thieme, L., Kunze, J., Eds.; Springer: Berlin, Germany, 2012.

84. Ackert, L.F. Traditional and behavioral finance. In Investor Behavior: The Psychology of Financial Planning and Investing; Baker, H.K., Ricciardi, V., Eds.; John Wiley \& Sons: Hoboken, NJ, USA, 2014.

(C) 2019 by the author. Licensee MDPI, Basel, Switzerland. This article is an open access article distributed under the terms and conditions of the Creative Commons Attribution (CC BY) license (http://creativecommons.org/licenses/by/4.0/). 